\title{
Development of water quality index of ex-mining ponds in Malaysia
}

\author{
Isa Baba Koki ${ }^{\text {a, b, }}{ }^{*}$, Sharifuddin Md Zain ${ }^{a}$, Kah Hin Low ${ }^{a}$, Azman Azid ${ }^{c}$, Hafizan Juahir ${ }^{d}$, Munirah \\ Abdul Zali ${ }^{\text {e }}$ \\ a Department of Chemistry, Faculty of Science, University Malaya, Kuala Lumpur 50603, Malaysia \\ ${ }^{b}$ Department of Chemistry, Yusuf Maitama Sule University Kano, PMB 3220 Kano Nigeria \\ c Faculty of Bioresources and Food Industry, Universiti Sultan Zainal Abidin, Besut Campus, 22200 Besut, Terengganu, Malaysia \\ ${ }^{d}$ East Coast Environmental Research Institute (ESERI), University Sultan Zainal Abidin, Kuala Terengganu, Malaysia \\ e Environmental Health Division, Department of Chemistry Malaysia, Jalan Sultan, 46661 Petaling Jaya, Selangor, Malaysia \\ *Corresponding author: isakoki@yahoo.com
}

\section{Article history}

Received 28 March 2018

Revised 5 June 2018

Accepted 14 August 2018

Published Online 4 February 2019

\begin{abstract}
In this paper, a study on the development of water quality index of ex-mining ponds was carried out for proper assessment and utilization of the abundant ex-mining ponds in Malaysia. Heavy metals were analyzed using inductively coupled plasma mass spectrophotometer (ICPMS), and physico chemical parameters were analyzed in-situ. Chemometric analysis was successfully applied for the parameter selection process. The water quality index of existing Malaysian river did not accommodate the toxic metal pollutants that dominanted in ex-mining water. The acceptable index should therefore incorporate the metal pollutants in order to evaluate the quality status of ex-mining water for human consumption which is the major point of consideration. Two water quality indices were developed to assess the water quality status of ex-mining ponds with reference to Malaysia's water quality standard (INWQS). The heavy metal index was comprised of contribution from $\mathrm{Pb}, \mathrm{As}$, and $\mathrm{Cd}$ as the selected metals, while the physico-chemical parameter index has BOD, $\mathrm{pH}, \mathrm{DO}$, and AN. Chemometric analysis revealed the dominance of the selected heavy metals in ex-mining water, and physico-chemical parameters were important in water quality monitoring. Heavy metal water quality index revealed that most ex-mining ponds in Klang Valley were classified to be very poor hence could not be used for human consumption. Due to domestic input in some of the lakes in Klang Valley, the physico-chemical water quality index was in very poor status as well. In Melaka and Negeri Sembilan, ex-mining ponds and lakes were classified as excellent in both indices.
\end{abstract}

Keywords: Water quality index, chemometric, heavy metals, ex-mining pond, pollution

\section{INTRODUCTION}

Water quality is an important aspect of human life which illustrates the state or condition of water, which incorporating physical, chemical and biological characteristics, with respect to its acceptability for a specific purpose. There is a global concern on the quality of surface water for consideration as source of supply for human consumption and other domestic needs (Kazi et al., 2009). The environmental status of lakes is depended the type of the lake and its exposure to various factors in the environment. The impairment of water quality is associated with climate change and population growth. Hence, the quality of surface water is not only depended on natural environmental processes such as weathering, erosion and precipitation, but also depended on the influence of anthropogenic activities including urban, agricultural and industrial activities (Khatri and Tyagi, 2015). It is therefore pertinent to monitor and ensure that quality of surface water is assessed for beneficial uses. Water quality index (WQI) provides a simple and concise method for expressing the quality of surface water by the use of single numbers.

Malaysia as a major leading producer and exporter of tin with output of about 40,000 tonnes annually, recorded a huge success and economic gains from 1900 to 1942 . The production increased above 50,000 tonnes annually from 1974 to 1980 . This significantly has contributed to the industrial development of many countries around the globe. However, there was no proper environmental monitoring and enforcement during mining operations. This caused environmental degradation and creation of ponds filled with accumulated mining water (Balamurugan, 1991). The early tin mining in Malaysia was concentrated in the Ampang area near Kuala Lumpur, and consequently Selangor became one of the largest tin producers in Malaysia.

The shortage of water for daily human and domestic activities especially in the period of dry season has prompted the search for other sources of water supply. Based on the water crisis in Selangor in the year 2014 and Melaka in 1991 and 2002, this issue is needed to be addressed decisively. The abundant ex-mining ponds in Malaysia with large volumes of water has been suggested to support the daily water demand (Low et al., 2016; Koki et al., 2017). Consequently, consideration must be given to parameters associated with ex-mining water especially the toxic heavy metals that are mostly presented in high concentrations (Ashraf et al., 2011). However, there is no available WQI to assess the water quality status of the ex-mining ponds for its proper utilization. The WQI utilized in Malaysia to evaluate water quality of rivers (equation 1) does not accommodate the heavy metals (DOE, 2012; Low et al., 2016). This has prompted the need to develop an index with the required relevant parameters for proper evaluation and classification of the ex-mining water. 
$W Q I=(0.22 * S I D O)+(0.19 * S I B O D)+(0.16 * S I C O D)+$ $(0.15 * \operatorname{SIAN})+(0.16 * \mathrm{SISS})+(0.12 * \mathrm{SipH})$

where;

SIDO $=$ Sublndex DO

SIBOD $=$ Sublndex BOD

SICOD $=$ Sublndex COD

$\mathrm{SIAN}=$ Sublndex $\mathrm{NH}_{3}-\mathrm{N}$

SISS $=$ Sublndex SS

$\mathrm{SipH}=$ Sublndex $\mathrm{pH}$

$0 \leq \mathrm{WQI} \leq 100$

Different WQI's are formulated for various uses including general water quality assessment, specific type of water demand, and water quality management projects. But one of the major challenges in developing WQI is the selection of appropriate parameters that represented the overall water quality (Hernández-Romero et al., 2004). Most WQI developed are subjective in the parameter selection (Lumb et al., 2011), and this affected the suitability of the index for a specific end use (Misaghi et al., 2017). The chemometric analysis employed in this study was aimed to develop a suitable WQI for the accurate assessment of ex-mining ponds for human consumption and other beneficial purposes. Toxic pollutants related to mining, and other environmental/anthropogenic pollutants were taken into consideration.

The objective of this study was therefore to develop WQI for the assessment and classification of ex-mining ponds and lakes. At present, there is no established available WQI that considered both heavy metals and physico-chemical parameters for the purpose of drinking and domestic uses. The study then applied the index to the ex-mining ponds and lakes.

\section{EXPERIMENTAL}

\section{Study sites}

This study was focused on Selangor, Melaka and Negeri Sembilan (Fig. 1) based on their relevance of mining activity in Malaysia, and continuous increase in demand for water supply for daily use (Balamurugan, 1991; Azzlan et al., 2016). The existed variations in geological formations of the underlying rocks were significantly affected the metal levels and distributions (Teh and KIang, 2002; Ghani et al., 2008; Shirazi et al., 2015). The climate of the study areas was tropical rainforest with abundant rainfall, moderately hot and high humidity (Althuwaynee et al., 2012; Shirazi et al., 2013). Some of the study sites were surrounded by residential units, while some sites were placed far away from the cities. The ponds were mostly utilized for flood retention, agriculture, recreation, and deposition of domestic effluents.

The water samples were collected from ex-mining ponds and lakes in the study sites (Table 1) from September 2015 to October 2016 in the period of low rainfall, and analyzed in-situ for $\mathrm{pH}, \mathrm{DO}$, EC, TSS and AN using the YSI multiprobe, while BOD was measured using modern water BOD meter. The water samples were preserved at low temperature $\left(4^{\circ} \mathrm{C}\right)$ and acidic $\mathrm{pH}(<2)$ for the laboratory analysis. The triplicates of each water sample were filtered using $0.45 \mu \mathrm{m}$ PTFE filters before conducting metal analysis using inductively coupled plasma-mass spectrophotometry (ICP-MS). The filtered water samples were analysed for $\mathrm{As}, \mathrm{Cd}, \mathrm{Pb}, \mathrm{Mn}, \mathrm{Fe}, \mathrm{Na}, \mathrm{Mg}$, and $\mathrm{Ca}$ with ICP-MS 7500ce (Agilent Scientific Technology Ltd., USA) (Koki et al., 2017).

\section{Quality control}

All the reagents used in this study were analytical grade. The plastic-wares used were soaked in $15 \% \mathrm{HNO}_{3}(\mathrm{v} / \mathrm{v})$, and rinsed twice with ultrapure water (UPW) produced from the PURELAB ${ }^{\circledR}$ UHQ II system $\left(\mathrm{ELGA}^{\circledR}, \mathrm{UK}\right)$. UPW was also used in the preparation of blanks and standard solutions. The multi elemental calibration stock solutions of $1000 \mathrm{mg} / \mathrm{L}$ for $\mathrm{Fe}, \mathrm{Na}, \mathrm{Ca}$ and $\mathrm{Mg}$, while $10 \mathrm{mg} / \mathrm{L}$ for As, $\mathrm{Cd}, \mathrm{Pb}$, and $\mathrm{Mn}$ (Agilent Technologies, Newcastle) were used to prepare the calibration and quality control (QC) solutions by appropriate dilution. The standard reference materials for ICP Certipur $^{\circledR}$ (Merck, Germany), SLR-4 riverine water reference material for trace metals (National Research Council of Canada), and National Institute of Science and Technology standard reference materials for trace elements in water (NIST 1643f, USA) were used to validate and verify the ICP-MS procedure. Blank and QC samples were checked after every ten samples to demonstrate the validity of the previous runs. All analyses were carried out in triplicates and the results were expressed as $95 \%$ confidence interval of the mean in $\mu \mathrm{g} / \mathrm{L}$ (Koki et al., 2017; Koki et al., 2018).

\section{Data analysis}

The chemometric analyses including principal component analysis (PCA), hierarchical cluster analysis (HCA), and linear discriminant analysis (LDA) applied in the parameter selection were carried out using JMP Pro12. PCA identified the most significant or meaningful parameters in the data set, resulted in reducing the complexity of the data and giving a better understanding of the variation among the parameters (Mustapha et al., 2013). HCA was used on the standardized data set to group similar sampling sites using wards method with euclidean distance as the measure of similarity (Zain et al., 2016). LDA established a discriminant function that could predict the identity of sample group by further confirming the results of HCA and evaluating the variations with respect to the discriminant variables. The water quality index formulation was carried out using MS Excel 2013.

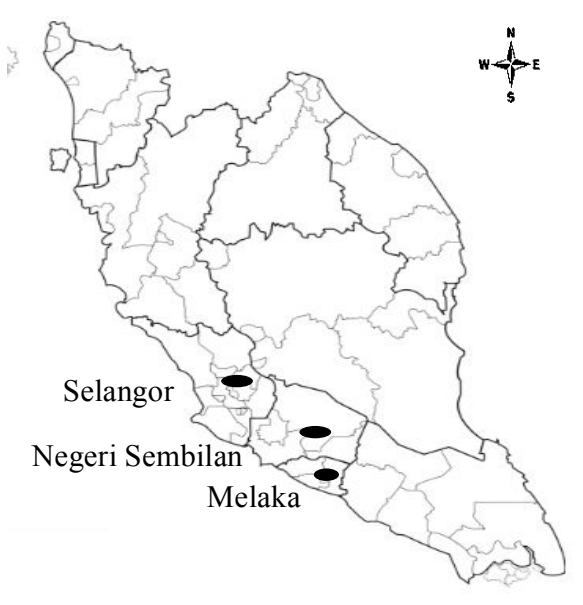

Fig. 1 Map of Malaysia showing the study locations.

\section{Parameter selection}

For water intended for human consumption, priority was given to parameters of health concern (Ashraf et al., 2010), as much concerns had been raised on levels of heavy metals in ex-mining water (Ashraf et al., 2010; Ashraf et al., 2011; Atanacković et al., 2013). In this regard, toxic metals associated with mining were-the main focus on the final decision because conventional water treatment processes was only considered and regulated physical-chemical parameters through a sequential process of rapid mixing, flocculation, sedimentation, filtration, and disinfection (Asami et al., 2016; Ayekoe et al., 2017). Similarly, $\mathrm{pH}, \mathrm{BOD}$, and DO were considered easily via purified parameters and skillful handling in the water treatment plants (Hou et al., 2016). However, toxic metals were not removed during conventional water treatment processes, but were only removed by using expensive techniques such as forward osmosis, floatation, enhanced ultra-filtration and use of cellulose modified filters (Low et al., 2016; Huang et al., 2017; You et al., 2017). The parameters selected in the development of the WQI of ex-mining ponds were mostly highlighted in previous studies related to the pollutants in mining areas across the world including Malaysia (Yidana and Yidana, 2010; Abbasi and Abbasi, 2012; Gao et al., 2017;). The 
experimental results of this study would confirm the presence of these pollutants, especially the toxic heavy metals which were of much priority. Furthermore, PCA, HCA and LDA of the water samples from ex-mining ponds and lakes could justify the parameter selection (Koki et al., 2017). A study on the health risk assessment on exposure to the ex-mining water would also confirm the relevance of the selected parameters (Koki et al., 2018).

Chemometric techniques were applied in the parameter selection,in which the parameters selected for the development of WQI were based on metals that included $\mathrm{As}, \mathrm{Cd}$, and $\mathrm{Pb}$ while physical-chemical parameters included $\mathrm{pH}, \mathrm{DO}, \mathrm{BOD}$, and $\mathrm{AN}$. These selected parameters would reflect the general water quality for the intended use, thereby reducing the subjectivity in the parameter selection process that was mostly done by experts in the development of the pioneer and popular existing indices (Gupta et al., 2013).

\section{Weightage assignment}

Assigning weightage to the selected parameters was an important stage in developing WQI as it entailed in assigning a significance or priority in the form of a numerical value to the individual parameters in accordance with the contribution to the overall water quality (Bhutiani et al., 2016). The standard permissible values of the parameters in Malaysian water quality standard INWQS were used to assign the weightages that added up to 1 . The selected parameters and the allocated weightages respectively for metals and physicalchemical parameters were shown in Tables 2 and 3. From Table 2, it could be inferred that toxic heavy metals associated with mining have a total relative weight of 453 which was by far greater than 3.98 for the physical-chemical parameters as shown in Table 3. The high relative weight of metals was due to the low standard permissible values in drinking water (DOE, 2012; $\mathrm{MOH}, 2004)$. The assigned weightage factors of the metal pollutants were $0.74,0.22$, and 0.04 for $\mathrm{Cd}, \mathrm{As}$, and $\mathrm{Pb}$ respectively. The weightage was given by equation 2 ;

$$
W=\frac{K}{S}
$$

where $\mathrm{W}$ is the weightage, $\mathrm{K}$ is proportionality constant, and $\mathrm{S}$ is the parameter standard permissible value (Jha et al., 2015; Saeedi et al., 2010).

Equation 2 could be rewritten as follows;

$$
K=\frac{1}{\sum_{1}^{n 1}}
$$

\section{Subindex/quality rating}

Sub-indices could transform different units of the water quality parameters into a common scale (MERC, 2012). The quality rating of each selected parameter could be achieved either by using mathematical equations or rating curves formulated by opinion of the selected water quality experts. Several researchers pointed the highly subjective nature of the rating curves (Cude, 2001; Boyacioglu, 2007). Similarly, the use of sub-index rating based on the personal opinion of 14 water quality experts in the formulation of the universal water quality index was reported (Vasanthavigar et al., 2010). However, quality rating using observed experimental values (primary data) was applied to obtain the sub-indices in this study. It was actually the ratio of the parameter concentration in the water sample to the standard permissible value (Abbasi and Abbasi, 2012), as given in equations 4 and 5 below. This was more acceptable by considering that water from the ex-mining ponds was proposed for human consumption.

$$
\begin{gathered}
Q_{i}=\frac{C_{i}}{S_{i}} \times 100 \\
Q_{p H, D O}=\frac{C_{i}-V_{i}}{S_{i}-V_{i}} \times 100
\end{gathered}
$$

where $C_{i}$ is the parameter concentration in $\mathrm{mg} / \mathrm{L}, \mathrm{S}_{\mathrm{i}}$ is the standard parameter value in INWQS, $\mathrm{V}_{\mathrm{i}}$ is the ideal value which is considered as 7.0 for $\mathrm{pH}$, and 14.6 for DO. The sub-index was further computed using equation 6 .

$$
S I_{i}=W_{i} \times Q_{i}
$$

\begin{tabular}{|c|c|c|c|c|}
\hline Type & Location & Area & Code & Coordinate \\
\hline \multirow{12}{*}{$\begin{array}{l}\text { Ex-mining } \\
\text { pond }\end{array}$} & \multirow{8}{*}{ Selangor } & \multirow{4}{*}{ Puchong } & TSP & $\begin{array}{l}{\mathrm{N} 02^{\circ}}^{\circ} 56^{\prime} 50.4^{\prime \prime} \\
\mathrm{E} 101^{\circ} 34^{\prime} 37.2^{\prime \prime}\end{array}$ \\
\hline & & & TPPA & $\begin{array}{c}{\mathrm{N} 02^{\circ}}^{\circ} 57^{\prime} 27.8^{\prime \prime} \\
\mathrm{E} 101^{\circ} 36^{\prime} 52.2^{\prime \prime}\end{array}$ \\
\hline & & & TPPB & $\begin{array}{l}\mathrm{N} 02^{\circ} 57^{\prime} 46.4^{\prime \prime} \\
\mathrm{E} 101^{\circ} 36^{\prime} 21.8^{\prime \prime}\end{array}$ \\
\hline & & & TPRP & $\begin{array}{l}\mathrm{N} 02^{\circ} 59^{\prime} 10.0^{\prime \prime} \\
\mathrm{E} 101^{\circ} 35^{\prime} 49.4^{\prime \prime}\end{array}$ \\
\hline & & Titiwangsa & TT & 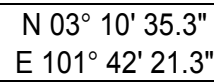 \\
\hline & & \multirow{2}{*}{$\begin{array}{l}\text { Kelana } \\
\text { Jaya }\end{array}$} & TKJA & $\begin{array}{l}\mathrm{N} 03^{\circ} 05^{\prime} 35.4^{\prime \prime} \\
\mathrm{E} 101^{\circ} 35^{\prime} 53.2^{\prime \prime}\end{array}$ \\
\hline & & & TKJB & $\begin{array}{l}\mathrm{N} 03^{\circ} 05^{\prime} 57.1^{\prime \prime} \\
\mathrm{E} 101^{\circ} 35^{\prime} 40.9^{\prime \prime}\end{array}$ \\
\hline & & Gombak & TB & $\begin{array}{c}\mathrm{N} 03^{\circ} 14^{\prime} 50.9^{\prime \prime} \\
\mathrm{E} 101^{\circ} 31^{\prime} 38.6^{\prime \prime}\end{array}$ \\
\hline & \multirow{3}{*}{ Melaka } & \multirow{3}{*}{ Jasin } & TBC1 & $\begin{array}{c}\mathrm{N} 02^{\circ} 16^{\prime} 13.8^{\prime \prime} \\
\text { E } 102^{\circ} 29^{\prime} 17.0^{\prime \prime}\end{array}$ \\
\hline & & & TBC2 & $\begin{array}{l}\mathrm{N} 02^{\circ} 16^{\prime} 15.8^{\prime \prime} \\
\text { E } 102^{\circ} 29^{\prime} 37.9^{\prime \prime}\end{array}$ \\
\hline & & & TBC3 & $\begin{array}{c}\mathrm{N} 02^{\circ} 16^{\prime} 27.3^{\prime \prime} \\
\mathrm{E} 102^{\circ} 29^{\prime} 34.6^{\prime \prime}\end{array}$ \\
\hline & $\begin{array}{c}\text { Negeri } \\
\text { Sembilan }\end{array}$ & Rantau & TR & $\begin{array}{c}\mathrm{N} 02^{\circ} 31^{\prime} 00.3^{\prime \prime} \\
\text { E } 101^{\circ} 57^{\prime} 47.7^{\prime \prime}\end{array}$ \\
\hline \multirow{9}{*}{ Lake } & \multirow{5}{*}{ Selangor } & $\begin{array}{l}\text { Petaling } \\
\text { Jaya }\end{array}$ & TTJA & $\begin{array}{l}\mathrm{N} 03^{\circ} 06^{\prime} 17.8^{\prime \prime} \\
\mathrm{E} 101^{\circ} 38^{\prime} 53.0^{\prime \prime}\end{array}$ \\
\hline & & \multirow{2}{*}{$\begin{array}{l}\text { Shah } \\
\text { Alam }\end{array}$} & TSA & $\begin{array}{l}{\mathrm{N} 03^{\circ}}^{\circ} 04^{\prime} 27.0^{\prime \prime} \\
\mathrm{E} 101^{\circ} 30^{\prime} 47.3^{\prime \prime}\end{array}$ \\
\hline & & & TS7 & $\begin{array}{l}\mathrm{N} 03^{\circ} 04^{\prime} 42.4^{\prime \prime} \\
\mathrm{E} 101^{\circ} 29^{\prime} 28.7^{\prime \prime}\end{array}$ \\
\hline & & Putrajaya & TPJ & $\begin{array}{l}{\mathrm{N} 02^{\circ}}^{\circ} 55^{\prime} 12.5^{\prime \prime} \\
\mathrm{E} 101^{\circ} 40^{\prime} 52.6^{\prime \prime}\end{array}$ \\
\hline & & $\begin{array}{l}\text { Kuala } \\
\text { Lumpur }\end{array}$ & TP & $\begin{array}{c}\mathrm{N} 03^{\circ} 08^{\prime} 31.9^{\prime \prime} \\
\mathrm{E} 101^{\circ} 41^{\prime} 06.5^{\prime \prime}\end{array}$ \\
\hline & \multirow{4}{*}{ Melaka } & \multirow{2}{*}{ Jasin } & JD & $\begin{array}{c}\mathrm{N} 02^{\circ} 26^{\prime} 38.3^{\prime \prime} \\
\mathrm{E} 102^{\circ} 24^{\prime} 00.2^{\prime \prime}\end{array}$ \\
\hline & & & TTB & $\begin{array}{l}\mathrm{N} 02^{\circ} 16^{\prime} 38.0^{\prime \prime} \\
\mathrm{E} 102^{\circ} 29^{\prime} 05.5^{\prime \prime}\end{array}$ \\
\hline & & Alor Gajah & TDT & $\begin{array}{l}\mathrm{N} 02^{\circ} 21^{\prime} 11.4^{\prime \prime} \\
\text { E } 102^{\circ} 17^{\prime} 55.6^{\prime \prime}\end{array}$ \\
\hline & & Bukit Katil & TBK & $\begin{array}{l}\mathrm{N} 02^{\circ} 16^{\prime} 30.94^{\prime \prime} \\
\mathrm{E} 102^{\circ} 17^{\prime} 08.30^{\prime \prime}\end{array}$ \\
\hline
\end{tabular}

The sub-indices of the selected parameters in ex-mining ponds and lakes were shown in Tables 4 and 5.

Table 1 Description of the study areas.

Table 2 Weighting factor of the selected heavy metals parameters.

\begin{tabular}{cccc}
\hline Parameter & $\begin{array}{c}\text { Standard Values } \\
\text { (INWQS, MOH) }\end{array}$ & $\begin{array}{c}\text { Relative } \\
\text { Weight }\end{array}$ & $\begin{array}{c}\text { Assigned } \\
\text { Weighting Factor }\end{array}$ \\
\hline As & 0.01 & 100 & 0.22 \\
$\mathrm{Cd}$ & 0.003 & 333 & 0.74 \\
$\mathrm{~Pb}$ & 0.05 & 20 & 0.04 \\
\hline Total & & $\mathbf{4 5 3}$ & $\mathbf{1}$ \\
\hline
\end{tabular}


Table 3 Weighting factor of the selected physical-chemical parameters.

\begin{tabular}{cccc}
\hline Parameter & $\begin{array}{c}\text { Standard } \\
\text { Values } \\
\text { (INWQS, MOH) }\end{array}$ & $\begin{array}{c}\text { Relative } \\
\text { Weight }\end{array}$ & $\begin{array}{c}\text { Assigned } \\
\text { Weighting } \\
\text { Factor }\end{array}$ \\
\hline $\mathrm{pH}$ & 8.5 & 0.117 & 0.03 \\
$\mathrm{AN}$ & 0.3 & 3.33 & 0.84 \\
$\mathrm{DO}$ & 5 & 0.2 & 0.05 \\
$\mathrm{BOD}$ & 3 & 0.33 & 0.08 \\
\hline Total & & $\mathbf{3 . 9 8}$ & $\mathbf{1}$ \\
\hline
\end{tabular}

\section{RESULTS AND DISCUSSION}

\section{Development of water quality index}

From Table 2, it could be inferred that toxic heavy metals associated with mining have a relative weight of 453 which was by far greater than 3.98 for the physical-chemical parameters as shown in Table 3. The assigned weightages factors of the metal pollutants were $0.74,0.22$, and 0.04 for $\mathrm{Cd}, \mathrm{As}$, and $\mathrm{Pb}$ respectively. This finding was in good agreement with levels of the selected metal pollutants in this study (Fig. 2), and their maximum permissible limits in drinking water. Besides the very high levels of $\mathrm{Cd}$ in four of the ex-mining ponds (TPPA, TPPB, TPRP and TT) and lake TPJ, Cd has the least maximum permissible limit in drinking water of $3 \mu \mathrm{g} / \mathrm{L}$ (MOH, 2004; DOE, 2012). AN has the highest weightage of 0.83 in the physicalchemical parameter index and this result agreed with the levels of domestic sewage discharge into the ex-mining ponds and lakes. AN is toxic to humans, animals, and plants, therefore it is not desirable in drinking water (Ashraf et al., 2011; Willingham et al., 2016; Dahlberg et al., 2016). This suggested the suitability of the indices in assessing the quality of water from ex-mining ponds that was-redominantly loaded with toxic heavy metals (Atanacković et al., 2013; Ning et al., 2011; Bhuiyan et al., 2010).

The chemometric study using PCA and LDA also revealed that larger variation in ex-mining ponds was associated with the toxic heavy metals. The PC1 and PC2 showed larger variation with $35.6 \%$ and $19.2 \%$ of the total variance, respectively (Fig. 3). The parameters that have strong positive loading on $\mathrm{PC} 1$ were $\mathrm{As}, \mathrm{Pb}, \mathrm{Cd}, \mathrm{Mg}, \mathrm{EC}$, and TDS as the major contributors. This indicated that pollution was very much related to the past mining activities. PC2 contained strong negative loading on $\mathrm{pH}$ and positive loading on BOD, indicating the dominance of organic matter and domestic discharge (Koki et al., 2017). Similarly, $\mathrm{As}, \mathrm{Pb}$ and Fe were reported as the most significant parameters in PC1 due to mining (Lumb et al., 2011). Additionally, comparison of the study parameter variations with respect to the sampling sites in Klang Valley and Melaka using HCA revealed high $\mathrm{As}$ and $\mathrm{Cd}$ concentrations in Klang Valley ex-mining ponds compared to lakes and also higher than all the sites in Melaka (Koki et al., 2018). This was attributed to the differences in the geology of the study areas and the anthropogenic activities. The results of LDA revealed a good sample prediction in which $\mathrm{Cd}$, As, $\mathrm{Mn}, \mathrm{Mg}$ and $\mathrm{DO}$ wereassociated with ex-mining ponds along the direction of canonical 1, whereas $\mathrm{pH}, \mathrm{AN}, \mathrm{Fe}$ and $\mathrm{SS}$ were associated with the lakes. This study also revealed that water samples analyzed from the ex-mining ponds have very low total suspended solid and were not turbid, resulting in clear surface water. This justified the low relative weight associated with the physical-chemical parameters.

The WQI was computed by summing up the sub-indices of the individual parameters to obtain the overall index as shown in equation 7 ;

$$
W Q I=\sum S I_{i}
$$

where SI is the sub-index of the individual parameter. The WQI of the ex-mining ponds and lakes with respect to heavy metals (WQI $\mathrm{HM}_{\mathrm{H}}$ ) was calculated using equation 8 below;

$$
W Q I_{H M}=0.74 * S I C d+0.22 * S I A s+0.04 * S I P b
$$

where SIAs is the sub index for As, SICd is sub index for $\mathrm{Cd}$, and $\mathrm{SIPb}$ is sub index for $\mathrm{Pb}$.

The WQI for the physical-chemical parameters (WQI $\mathrm{IC}_{\mathrm{PC}}$ was calculated using equation 9 below;

$$
W Q I_{P C}=0.03 * \operatorname{SIpH}+0.84 * \operatorname{SIAN}+0.08 * \operatorname{SIBOD}+0.05 * \operatorname{SIDO}
$$

where $\mathrm{SIpH}$ is sub index for $\mathrm{pH}$, SIAN is sub index for AN, SIBOD is sub index for BOD, SIDO is sub index for DO.

The WQI was classified into five categories as shown in Table 4. The classification was based on decreasing scale in which the water quality was increased along with the decreasing of WQI (Abbasi and Abbasi, 2012). The results of the classification revealed a significant difference in the $\mathrm{WQI}_{\mathrm{HM}}$ values among the sites studied in the Klang Valley $(\mathrm{p}<0.05)$. The ex-mining ponds (TPPA, TPPB, TPRP and TT) and lake TPJ were very polluted and rated poor with $\mathrm{WQI}_{\mathrm{HM}}$ of 302 557 and 315, respectively (Table 5). The water wasis classified as not suitable for human consumption due to high metal loadings. Nevertheless, all other ex-mining ponds and lakes in Klang Valley that having metal pollutants below INWQS limits were rated excellent with $\mathrm{WQI}_{\mathrm{HM}}$ of $1.4-33$ as displayed in Fig. 4. Table 6 shows that physical-chemical parameters ratings for all the ex-mining ponds and lakes wereas Good to Excellent except for TKJB, TTJA, and TS7 with $\mathrm{WQI}_{\mathrm{PC}}$ values of 120,118 , and 163 respectively. These sites were high with organic matter pollution from residences and other anthropogenic inputs (Fig. 5). The dissimilarity in $\mathrm{WQI}_{\mathrm{PC}}$ among the studied sites also confirmed the differences in the pollution sources and influences of external or anthropogenic input. Therefore, $\mathrm{WQI}_{\mathrm{PC}}$ would help to maintain a good water quality of lakes and ex-mining ponds. Conversely, no significant difference was observed in the WQI values of ex-mining ponds and lakes in Melaka. Tables 7 and 8 show $\mathrm{WQI}_{\mathrm{HM}}$ and $\mathrm{WQI}_{\mathrm{PC}}$ as excellent from 4.0-25 and 15-89 respectively where these ratings qualified the water for human consumption after proper conventional water treatment processes (Fig. 6 and Fig. 7).

Table 4 Water Quality classification.

\begin{tabular}{cc}
\hline Range & Water Quality Rating \\
\hline$<50$ & Excellent water \\
$50-100$ & Good water \\
$100-200$ & Poor water \\
$200-300$ & Very poor water \\
$>300$ & Water unsuitable for drinking purposes \\
\hline
\end{tabular}

Table 5 Sub-indices of the selected heavy metals and WQI $\mathrm{HM}_{\mathrm{M}}$ of exmining ponds and lakes in Klang valley.

\begin{tabular}{cccccc}
\hline Station & $\mathbf{A s}$ & $\mathbf{C d}$ & $\mathbf{P b}$ & $\mathbf{W Q I}_{\mathrm{HM}}$ & Status \\
\hline TPPA & 24.928 & 316.050 & 0.396 & 341.373 & Very Polluted \\
TPPB & 255.780 & 299.635 & 0.317 & 555.732 & Very Polluted \\
TPRP & 92.610 & 298.655 & 0.326 & 391.591 & Very Polluted \\
\hline TSP & 1.477 & 27.930 & 1.188 & 30.595 & Excellent \\
TT & 4.697 & 297.675 & 0.309 & 302.681 & Very Polluted \\
TKJA & 16.537 & 0.735 & 0.020 & 17.293 & Excellent \\
TKJB & 14.994 & 2.205 & 0.069 & 17.268 & Excellent \\
TB & 1.169 & 0.245 & 0.004 & 1.418 & Excellent \\
TTJA & 2.492 & 8.085 & 0.046 & 10.622 & Excellent \\
TP & 8.379 & 1.470 & 0.032 & 9.881 & Excellent \\
TSA & 7.431 & 0.490 & 0.004 & 7.925 & Excellent \\
TS7 & 31.752 & 1.225 & 0.058 & 33.035 & Excellent \\
TPJ & 16.537 & 298.165 & 0.387 & 315.089 & Very Polluted
\end{tabular}



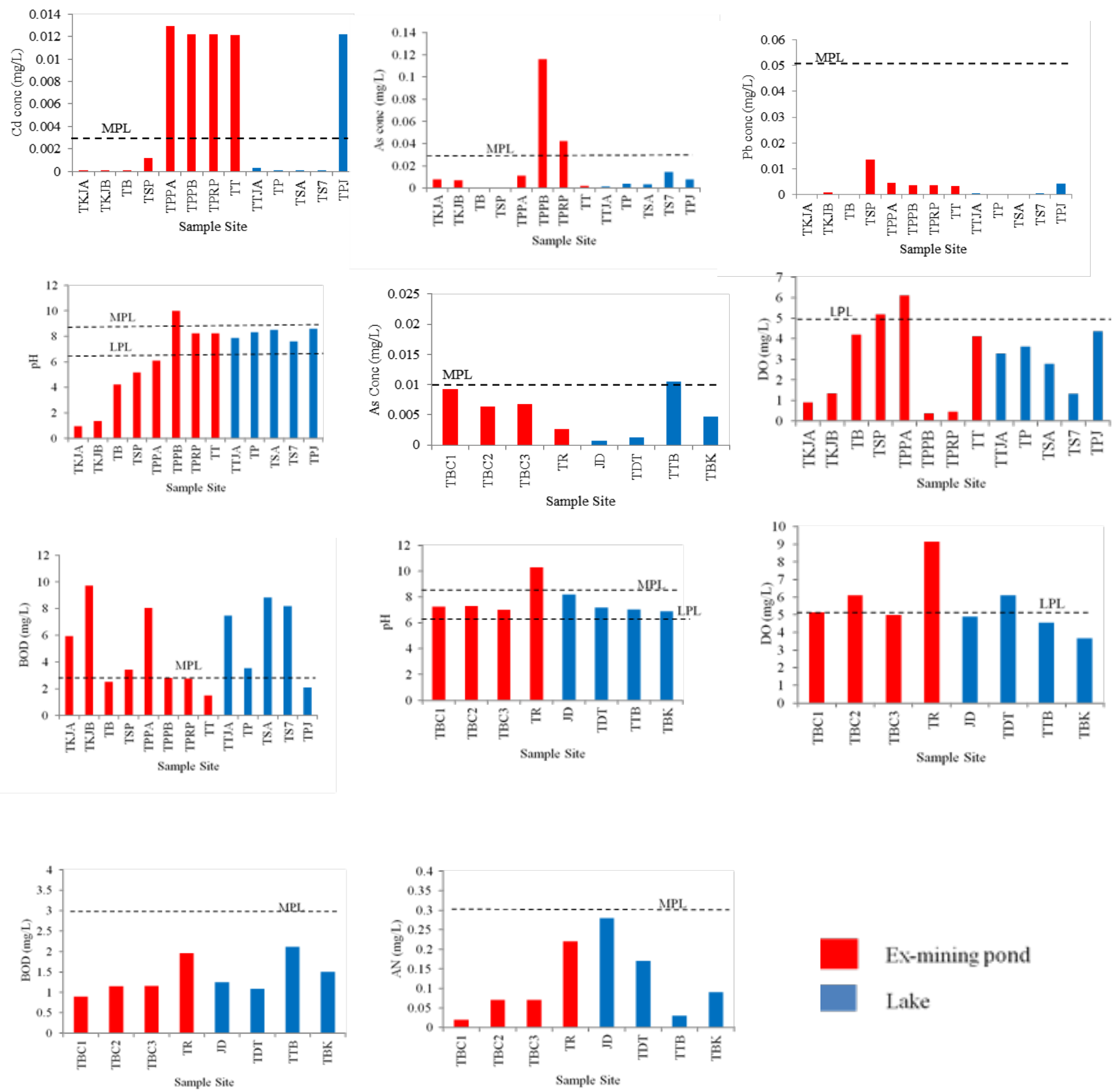

Ex-mining pond

Lake

$\mathrm{MPL}=$ Maximum permissible limit, $\mathrm{LPL}=$ Lower permissible limit

Fig. 2 Heavy metal levels and physical-chemical parameters in ex-mining ponds and lakes in Klang Valley, Melaka and Negeri Sembilan.

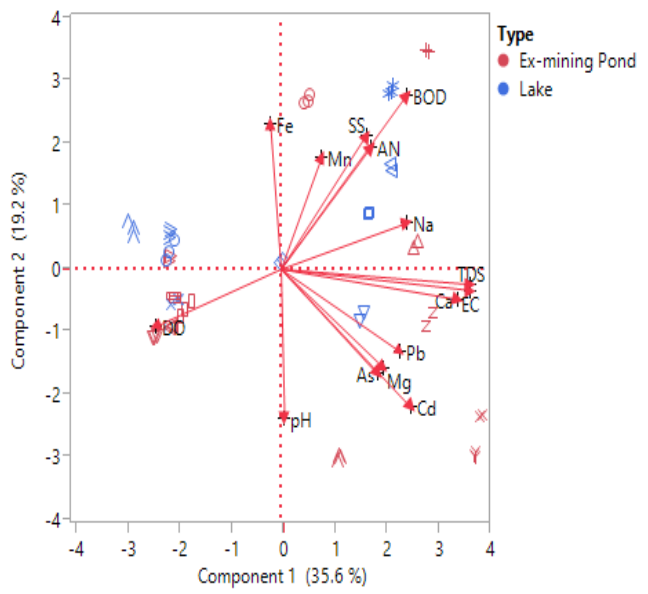

Fig. 3 PCA bi-plot of metals and physical-chemical parameters in ex-mining ponds and lakes in Klang Valley, Melaka and Negeri Sembilan. 
Table 7 Sub-indices of the selected heavy metals and WQI ${ }_{\text {HM }}$ of exmining ponds and lake in Melaka and Negeri Sembilan.

\begin{tabular}{cccccc}
\hline Station & As & Cd & Pb & WQI $_{\text {HM }}$ & Status \\
\hline TBC1 & 20.462 & 2.45 & 0.0088 & 22.921 & Excellent \\
TBC2 & 14.089 & 2.45 & 0.0088 & 16.548 & Excellent \\
TBC3 & 14.972 & 2.45 & 0.0088 & 17.431 & Excellent \\
TR & 5.777 & 2.45 & 0.0088 & 8.236 & Excellent \\
JD & 1.588 & 2.45 & 0.0088 & 4.046 & Excellent \\
TDT & 2.822 & 2.45 & 0.0088 & 5.281 & Excellent \\
TTB & 23.108 & 2.45 & 0.0088 & 25.567 & Excellent \\
TBK & 10.297 & 2.45 & 0.0088 & 12.756 & Excellent \\
\hline
\end{tabular}

Table 8 Sub-indices of the selected physical-chemical parameters and WQI $I_{P C}$ of ex-mining ponds and lakes in Melaka and Negeri Sembilan.

\begin{tabular}{lcccccc}
\hline Station & DO & BOD & pH & AN & WQI & Status \\
\hline TBC1 & 5.140 & 2.490 & 2.470 & 5.573 & 15.673 & Excellent \\
TBC2 & 6.110 & 3.182 & 2.494 & 19.506 & 31.292 & Excellent \\
TBC3 & 4.990 & 3.209 & 2.392 & 19.506 & 30.098 & Excellent \\
TR & 9.160 & 5.423 & 3.507 & 25.080 & 43.169 & Excellent \\
JD & 4.890 & 3.458 & 2.797 & 78.026 & 89.173 & Excellent \\
TDT & 6.090 & 3.016 & 2.449 & 47.373 & 58.928 & Excellent \\
TTB & 4.560 & 5.865 & 2.405 & 8.360 & 21.190 & Excellent \\
TBK & 3.670 & 4.150 & 2.347 & 25.080 & 35.247 & Excellent \\
\hline
\end{tabular}

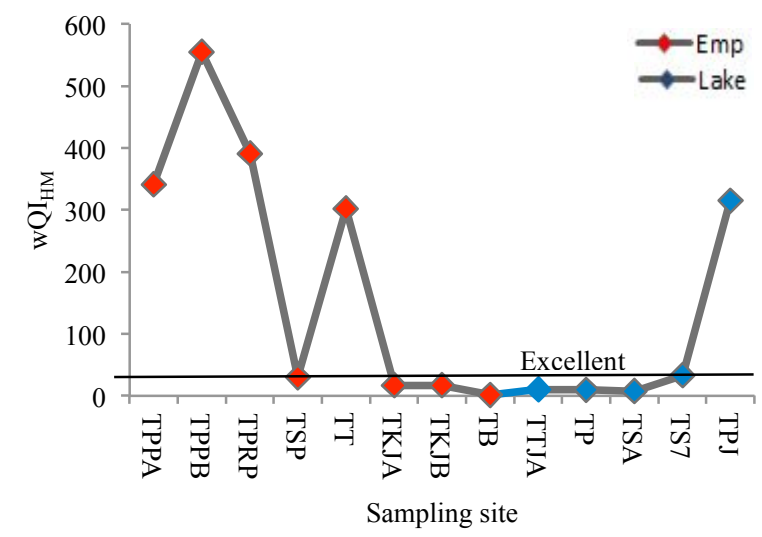

Fig. 4 Heavy metals $W{ }_{\text {HM }}$ of ex-mining ponds and lakes in Klang Valley.

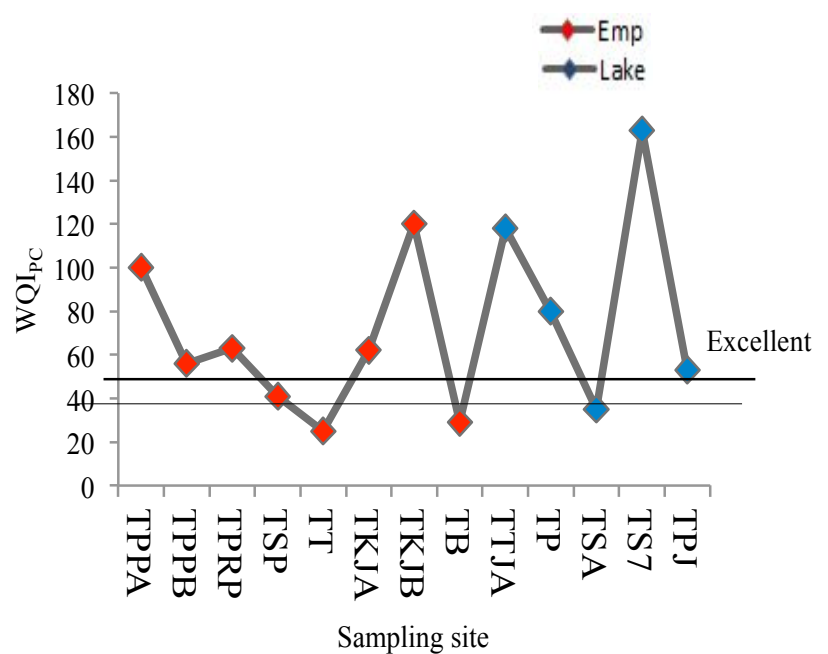

Fig. 5 Physical-chemical parameter $\left.W\right|_{P C}$ of ex-mining ponds and lakes in Klang Valley.

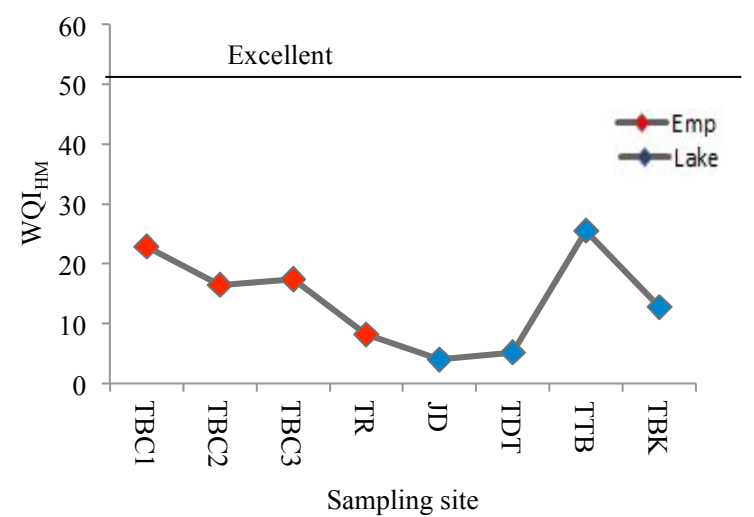

Fig. 6 Heavy metals $\left.W\right|_{H м}$ of ex-mining ponds and lakes in Melaka.

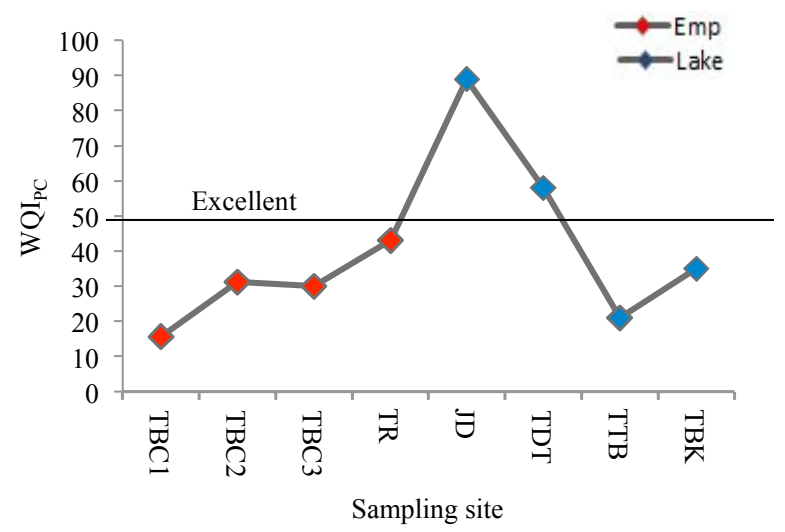

Fig. 7 Physical-chemical parameter $W Q I_{P C}$ of ex-mining ponds and lakes in Melaka

\section{Uncertainty in the development of water quality index}

Several WQI have been formulated and efforts have been made to address the limitations observed. All the WQI developed have advantages and limitations, but the limitations could be minimized by reducing the subjectivity (Lumb et al., 2011). Up till now, no single WQI has been accepted globally, but some countries have used combination of water quality data in their formulation. In this study, uncertainty was reduced to the barest minimum level by adopting established water quality guidelines (INWQS) separately for the heavy metals and physical-chemical parameters using chemometric approaches. In a similar way, the statistical approaches improved the accuracy and reliability of the index.

\section{CONCLUSION}

Water quality index of ex-mining ponds was developed in this study using Malaysian water quality standard as a reference in assigning weightage to the selected parameters. This approach employed the use of primary data and extensive literature comparisons in the parameter selection. Consideration was also given to the geology of the study areas, and anthropogenic inputs into the water bodies for the general water quality assessment. The chemometric and health risks evaluations were included to support the WQI development. Significant variations were observed in the levels of heavy metals and physical-chemical parameters in ex-mining ponds and lakes. This was attributed to the anthropogenic inputs especially in Klang Valley where As and $\mathrm{Cd}$ exceeded the reference limit in most ex-mining ponds. High levels of these toxic metals could also be plausibly linked to previous mining activities. As and $\mathrm{Cd}$ were the dominant and most important parameters in the metal $\mathrm{WQI}_{\mathrm{HM}}$, hence ex-mining ponds in Puchong (TPPA, TPPB, and TPRP), Titiwangsa (TT) and Putrajaya lake (TPJ) recorded to have very poor water quality and could not be utilized for drinking purposes but could be 
considered as relatively safe for recreational body contact. Other exmining ponds and lakes studied in the Klang Valley, Melaka and Negeri Sembilan have heavy metal $\mathrm{WQI}_{\mathrm{HM}}$ classification ranging from good to excellent, therefore might be utilized after proper treatment processes. Based on the physical-chemical parameter, $\mathrm{WQI}_{\mathrm{PC}}$, TKJB, TTJA, and TS7 in Klang Valley have poor water quality, hence the need to undergo further purification before utilization was crucial.

\section{ACKNOWLEDGEMENT}

The authors wish to acknowledge the financial support of University Malaya IPPP Grant [PG147-2014B].

\section{REFERENCES}

Abbasi, T., Abbasi, S. A. 2012. Water quality indices. Amsterdam: Elsevier.

Mustapha, A., Aris, A. Z, Juahir, H., Ramli, M. F., Kura, N. U. 2013. River water quality assessment using environmentric techniques: Case study of Jakara River Basin. Environ Sci Pollut Res., 20, 8, 5630-5644.

Althuwaynee, O. F., Pradhan, B., Lee, S. 2012. Application of an evidential belief function model in landslide susceptibility mapping. Comput Geosci, 44, 120-135.

Ashraf, M. A., Maah, M. J., Yusoff, I. B. 2010. Study of water quality and heavy metals in soil \& water of ex-mining area Bestari Jaya, peninsular Malaysia. Int. J. Basic Appl, Sci., 10, 3, 7-27.

Ashraf, M. A., Maah, M. J., Yusoff, I. 2011. Analysis of physio- chemical parameters and distribution of heavy metals in soil and water of exmining area of Bestari Jaya, Peninsular Malaysia. Asian J. Chem. 23, 8, 3493-3499.

Atanacković, N., Dragišić, V., Stojković, J., Papić, P., Živanović, V. 2013. Hydrochemical characteristics of mine waters from abandoned mining sites in Serbia and their impact on surface water quality. Environ Sci Pollut Res., $20,11,7615-7626$

Asami, T., Katayama, H., Torrey, J. R., Visvanathan, C., Furumai, H. 2016. Evaluation of virus removal efficiency of coagulation-sedimentation and rapid sand filtration processes in a drinking water treatment plant in Bangkok, Thailand. Water Res., 101, 84-94.

Ayekoe, C. Y., Robert, D., Lanciné, D. G. 2017. Combination of coagulationflocculation and heterogeneous photocatalysis for improving the removal of humic substances in real treated water from Agbô River (Ivory-Coast). Catal. Today., 281, 2-13.

Azzlan, A., Cheong, C. B., Lau, K. L. 2016. Sustainable water management for water supply efficiency: A case study at Syarikat Air Melaka Berhad. J. Technol. Manag. Bus., 3, 1, 1-21.

Balamurugan, G. 1991. Tin mining and sediment supply in Peninsular Malaysia with special reference to the Kelang River basin. Environmentalis 11, 281-291.

Bhuiyan, M. A., Parvez, L., Islam, M., Dampare, S. B., Suzuki, S. 2010. Heavy metal pollution of coal mine-affected agricultural soils in the northern part of Bangladesh. J. Hazard Mater., 173, 1, 384-392.

Bhutiani, R., Khanna, D., Kulkarni, D. B., Ruhela, M. 2016. Assessment of Ganga river ecosystem at Haridwar, Uttarakhand, India with reference to water quality indices. Appl Water Sci. 6, 2, 107-113.

Boyacioglu, H. 2007. Development of a water quality index based on a European classification scheme. Water $\mathrm{Sa}, 33,1,101-106$.

Cude, C. G. 2001. Oregon water quality index a tool for evaluating water quality management effectiveness. J. Am Water Resour Assoc., 37, 1, 125 137.

Dahlberg, D., Ivanovic, J., Hassel, B. 2016. Toxic levels of ammonia in human brain abscess. J. Neurosurg., 124, 3, 854-860.

DOE, 2012. Department of Environment. Malaysia: Environmental Quality Act Report, Ministry of Science, Technology and th Environment, Putrajaya, Malaysia.

Gao, Q., Li, Y., Cheng, Q., Yu, M., Hu, B., Wang, Z., Yu, Z. 2016. Analysis and assessment of the nutrients, biochemical indexes and heavy metals in the Three Gorges Reservoir, China, from 2008 to 2013. Water Res., 92, 262274.
Ghani, A., Azirun, M., Ramli, R., Hashim, R. 2008. Geochemical contrast between Beroga (Kuala Kelawang pluton) and Semenyih (Kuala Lumpur pluton) granites in Kuala Kelawang area, Negeri Sembilan. Bull. Geol. Soc. Malaysia, 54, 71-47.

Gupta, A., Gupta, S., Patil, R. S. 2003. A comparison of water quality indices for coastal water. J. Environ Sci Health A, 38, 11, 2711-2725.

Hernández-Romero, A. H., Tovilla-Hernández, C., Malo, E. A., BelloMendoza, R. 2004. Water quality and presence of pesticides in a tropical coastal wetland in southern Mexico. Mar. Pollut. Bull. 48, 11-12, 1130 1141.

Kazi T. G., Arain M. B., Jamali M. K., Jalbani N., Afridi H. I., Sarfraz R. A., Baig J. A., Shah A. Q. 2009. Assessment of water quality of polluted lake using multivariate statistical techniques: a case study. Ecotoxicol. Environ. Saf., 72, 301-309.

Khatri, N., Tyagi, S. 2015. Influences of natural and anthropogenic factors on surface and groundwater quality in rural and urban areas. Front Life Sci., 8, 1, 23-39.

Koki, I. B., Low, K. H., Juahir, H., Azid, A., Zain, S. M. 2017. Assessment of water quality of man-made lakes in Klang Valley (Malaysia): the impact of mining. Desalin Water Treat. 74, 125-136.

Koki, I. B., Low, K. H., Juahir, H., Azid, A., M. A. Zali, Zain, S. M., 2018. Consumption of water from ex-mining ponds in Klang Valley and Melaka, Malaysia: A health risk study. Chemosphere, 195, 641 - 652 .

Low, K. H., Koki, I. B., Juahir, H., Behkami, S., Ikram, R., Mohammed, H. A., Zain, S. M. 2016. Evaluation of water quality variation in lakes, rivers, and ex-mining ponds in Malaysia (review). Desalin. Water Treat, 57, 58, 2821528239.

Lumb, A., Sharma, T., Bibeault, J. F. 2011. A review of genesis and evolution of water quality index (WQI) and some future directions. Water Qual Expo Health, 3, 1, 11-24.

MERC. 2012. Study on the establishment of marine water quality index for Malaysia. Kuala Lumpur: Malaysian Environmental Resources Centre.

MOH. 2004. National Standard for Drinking Water Quality, Ministry of Health, Malaysia. Document D1.

Misaghi, F., Delgosha, F., Razzaghmanesh, M., Myers, B. 2017. Introducing a water quality index for assessing water for irrigation purposes: A case study of the Ghezel Ozan River. Sci Total Environ, 589, 107-116.

Ning, L., Liyuan, Y., Jirui, D., Xugui, P. 2011. Heavy metal pollution in surface water of Linglong gold mining area, China. Procedia Environ Sci, 10, 914-917.

Papatheodorou, G., Demopoulou, G., Lambrakis, N. 2006. A long-term study of temporal hydrochemical data in a shallow lake using multivariate statistical techniques. Ecol. Model., 193, 3, 759-776.

Saeedi, M., Abessi, O., Sharifi, F., Meraji, H. 2010. Development of groundwater quality index. Environ Monit Assess., 163, 1, 327-335.

Shirazi, S. M., Adham, M., Zardari, N. H., Ismail, Z., Imran, H. M., Mangrio, M. A. 2015. Groundwater quality and hydrogeological characteristics of Malacca state in Malaysia. J. Water Land Dev., 24, 1, 11-19.

Shirazi, S., Imran, H., Akib, S., Yusop, Z., Harun, Z. 2013. Groundwater vulnerability assessment in the Melaka State of Malaysia using DRASTIC and GIS techniques. Environ. Earth Sci., 70, 5, 2293-2304.

Teh, G., KIang, A. K. 2002. EPMA Characterisation and Geochemistry of Cas site rites from the Kuala Lumpur area. Bull. Geol. Soc. Malaysia, 45, 363368.

Vasanthavigar, M., Srinivasamoorthy, K., Vijayaragavan, K., Ganthi, R. R., Chidambaram, S., Anandhan, P., Manivannan, P., Vasudevan, S. 2010. Application of water quality index for groundwater quality assessment: Thirumanimuttar sub-basin, Tamilnadu, India. Environ Monit Assess., 171, 1-4, 595-609.

Willingham, W. T., Thurston, R. V., Luedtke, R. J., Russo, R. C. 2016. Toxicity of Ammonia and Nitrite to Aquatic Macroinvertebrates. Int. J. Sci., 22, 4, 138-139.

Yidana, S. M., Yidana, A. 2010. Assessing water quality using water quality index and multivariate analysis. Environ. Earth Sci., 59, 7, 1461-1473.

You, S., Lu, J., Tang, C. Y., Wang, X. 2017. Rejection of heavy metals in acidic wastewater by a novel thin-film inorganic forward osmosis membrane. Chem Eng J., 320, 532-538.

Zain, S. M., Behkami, S., Bakirdere, S., Koki, I. B. 2016. Milk authentication and discrimination via metal content clustering - A case of comparing milk from Malaysia and selected countries of the world. Food Control, 66, 306314 . 